\title{
BLOOD GLUTATHIONE LEVELS IN RHEUMATOID ARTHRITIS
}

\author{
BY \\ D. WATSON, D. S. BIDMEAD, and G. D. KERSLEY \\ From the Rheumatism Research Unit of the South West and Oxford Regions, \\ Royal National Hospital for Rheumatic Diseases, Bath
}

(RECEIVED FOR PUBLICATION SEPTEMBER 30, 1952)

It is well known that sulphydryl (SH) groups are necessary for the activity of important enzyme systems. Recent work by Rall and Lehninger (1952) indicates further, that the SH groups of glutathione play a direct part in electron carriage in cellular respiration. In view of the lesions found in the skeletal muscle in rheumatoid arthritis (Freund and others, 1945; Desmarais and others, 1948), we decided to ascertain whether the availability of the SH compounds of blood bore any relation to these rheumatoid changes. Preliminary experiments indicated that fluctuations in serum protein SH were too variable to relate to the clinical progress of the disease; this report concerns the glutathione content of the blood cells as this alone appeared to show some variation from normal.

\section{Method}

Blood analyses were first made by a nitroprusside method (Thompson and Watson, 1952) and later by an amperometric titration (Bidmead and Watson, 1952) which has been shown to give essentially the values obtained by the former procedure. Individual figures for glutathione sulphydryl (GSH) are accurate to \pm 2 per cent. and the mean results calculated are for clarity expressed to the nearest $\mathrm{mg} . / 100 \mathrm{ml}$. The packed cell volume was determined in Wintrobe tubes, and the reading, without white cells, was recorded to the nearest 0.5 per cent.

\section{Material}

Venous blood was obtained from:

(i) a group of rheumatoid patients,

(ii) healthy subjects under 45 years,

(iii) cases of anaemia having no history of rheumatism.

The third group was subdivided into patients who had suffered loss of blood within a period of 7 days prior to blood analysis and those with a longstanding anaemia without demonstrable blood loss or gross sepsis.

\section{Results}

Table I confirms the existence of a raised red cell content of glutathione in chronic anaemia. The blood GSH concentration in these cases remains unaltered, but is considerably depressed in the acutely anaemic group.

TABLE I

MEAN BLOOD GSH VALUES IN ANAEMIC CONTROLS N

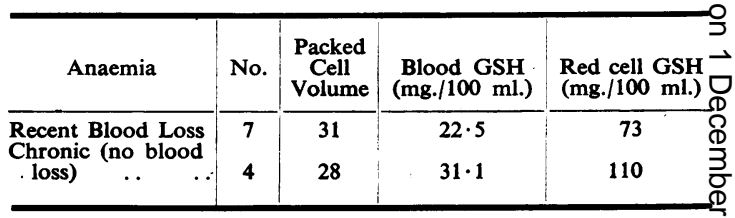

In Table II the mean values for rheumatoid patie are compared with a healthy control group. GSH levels of the rheumatoid patients were in addition examined to see if any noteworthy correlation existed between these levels and the activity orō duration of the disease, sex, or age. No significanto correlation was apparent except in so far as:

(1) a slightly higher packed cell volume for men $\overrightarrow{\vec{B}}$ attends a proportionately lower cell GSH value than 3 for women,

(2) cases with more highly active disease tend to have्ञ more severe anaemia and therefore a higher cell GSH: content.

TABle II

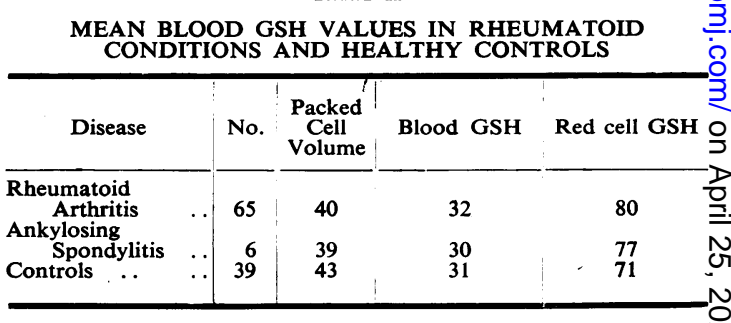

Table III gives the mean GSH concentration in ${ }_{\sigma}^{\omega}$ the whole blood and red cells of rheumatoid patients with differing degrees of anaemia (as judged by ㅡ을 haemoglobin levels). These results suggest that the severity of the anaemia has little effect on estimable GSH concentration in whole blood, but that a raised 
erythrocyte GSH content is present in the more anaemic cases.

TABLE III

MEAN BLOOD GSH VALUES IN RHEUMATOID ANAEMIA

\begin{tabular}{ccc|c|c|c|c}
\hline \multicolumn{2}{c|}{ Degree of } & Anaemia & & No. & Blood GSH & Red cell GSH \\
\hline None & $\ldots$ & $\ldots$ & $\ldots$ & 27 & 33 & 73 \\
Slight & $\ldots$ & $\ldots$ & $\ldots$ & 22 & 31 & 80 \\
Moderate &. & $\cdots$ & 16 & $30(0 \cdot 5)$ & 92 \\
\hline
\end{tabular}

A marked decrease in muscle GSH (in animals) and blood GSH in man (sometimes as much as 30 per cent.) has been reported following administration of growth hormone (Gregory and Goss, 1950), cortisone (Lazarow and Berman, 1950), and ACTH and hydrocortisone (Conn and others, 1948, 1949, 1951). A hyperglutathionaemia has been shown to follow the administration of DOCA (Binet and Poutonnet, 1943; Grunert and Phillips, 1949) and the production of an insulin hypoglycaemia in dogs. (Zunz, 1932-confirmed in our own laboratory in cases under treatment.) After administering ACTH, hydrocortisone, and cortisone acetate to three patients with rheumatoid arthritis, workers from the Mayo Clinic (Sprague and others, 1950) were unable to find any consistent pattern of change in blood GSH.

A number of estimations of red cell glutathionè were made during the course of treating nine cases of rheumatoid arthritis with ACTH $(100 \mathrm{mg}$. per day) and five cases with cortisone (200 mg. daily). In no case was a fasting glycosuria produced. No regular or consistent change in GSH level was found during the course of treatment. Two cases completely resistant to ACTH (Kersley and others, 1952) showed a slight degree of hypoglutathionaemia, but in the other cases no correlation between GSH levels and clinical response was found.

\section{Summary}

Using an improved method of estimation, erythrocyte glutathione levels in rheumatoid arthritis (before and after treatment) were investigated: no quantitative alteration attributable to the rheumatic process was found.

Any variations in GSH levels in rheumatoid arthritis appeared to be associated with the accompanying anaemia, and they support the haematological evidence already available (Jeffrey, 1952) that this anaemia is of haematopoietic origin rather than due to hydraemia. These results also agree with those of Joiner (1952).

Cortisone and ACTH produced no consistent changes in GSH, and when a slight depression of whole blood and cell glutathione occurred it was not necessarily related to clinical improvement.

We wish to thank the physicians and surgeons of the Royal United Hospital, Bath, the blood donors of the Royal National Hospital for Rheumatic Diseases, and members of this Unit for their co-operation.

\section{REFERENCES}

Bidmead, D. S., and Watson, D. (1952). J. clin. Path., 5, 30. Binet, L., and Poutonnet, M. (1943). Ann. Endocr., Paris, 4, 111. Conn, J. W., Louis, L. H., and Fajans, S. S. (1951). Science, 113, 713. - - and Johnston, M. W. (1949). J. Lab. clin. Med., 34, 255. 二, 二, and Wheeler, C. E. (1948). Ibid., 33, 651 .

Desmarais, M. H. L., Gibson, H. J., and Kersley, G. D. (1948). Annals of the Rheumatic Diseases, 7, 132.

Freund, H. A., Steiner, G., Leichtentritt, B., and Price, A. E. (1945). Science, 101, 202.

Gregory, P. W., and Goss, H. (1939). Growth, 3, 159.

Grunert, R. R., and Phillips, P. H. (1949). J. biol. Chem., 181, 821. Jeffrey, M. R. (1952). Annals of the Rheumatic Diseases, 11, 162. Joiner, C. L. (1952). Brit. med. J., 2, 642.

Kersley, G. D., Mandel, L., and Desmarais, M. H. L. (1952). Brit. med. J., 2,540 .

Lazarow, A., and Berman, J. (1950). Anat. Rec., 106, 215.

Rall, T. W., and Lehninger, A. L. (1952). J. biol. Chem., 194, 119.

Sprague, R. G., Power, M. H., Mason, H. L., Albert, A., Mathieson, D. R., Hench, P. S., Kendall, E. C., Slocumb, C. H., and Polley, H. F. (1950). Arch. intern. Med., 85, 199.

Thompson, R. H. S., and Watson, D. (1952). J. clin. Path., 5, 25.

Zunz, E. (1932). Arch. int. Physiol., 35, 65.

Taux sanguins de glutathion dans l'arthrite rhumatismale RÉSUMÉ

Le taux érythrocytaire de glutathion (GSH) dans l'arthrite rhumatismale (avant et après le traitement) fut déterminé au moyen d'un procédé amélioré de dosage. On ne trouva aucune altération quantitative que l'on puisse attribuer au processes rhumatismal.

Toutes les variations du taux de GSH paraissent être liées à l'anémie accompagnant l'arthrite rhumatismale, ce qui vient à l'appui des données hématologiques existantes (Jeffrey, 1952) tendant à établir l'origine hémopoïetique plutôt qu'hydrémique de cette anémie. Ces résultats s'accordent aussi avec ceux de Joiner (1952).

La cortisone et l'ACTH ne provoquèrent pas d'altérations uniformes du taux de GSH, et de légères diminutions rencontrées dans le sang total et dans les éléments figurés ne furent pas nécessairement en rapport avec l'amélioration clinique.

Tasa sanguínea de glutation en la artritis reumatoide SUMARIO

Se ha determinado, empleando un procedimiento perfeccionado de dosificación, las cifras eritrocitarias de glutation (GSH) en la artritis reumatoide, antes y después del tratamiento. No se encontró alteraciones cuantitativas que se pudiera atribuir al proceso reumatoide.

Todas las variaciones de la tasa de GSH parecen estar ligadas a la anemia asociada, lo que añade una prueba más a los datos hematológicos existentes (Jeffrey, 1952) que establecen el origen hemopoyético más bien que hidrémico de esta anemia. Estos resultados cơncordan también con los de Joiner (1952).

La cortisona y la ACTH no motivaron alteraciones uniformes de la tasa de GSH; las ligeras bajas de glutation que ocurríeron en la sangre total y en los glóbulos no estuvieron necesariamente en relación con las mejorías clínicas. 